\title{
Assessment of the Property Complex in the Management of an Integrated Agro-Industrial Enterprise
}

\author{
Lytneva N.* \\ Central Russian Management Institute, Russian Academy of \\ National Economy and Public Administration affiliated with \\ the Russian President \\ Orel, Russia \\ e-mail: ukap-lytneva@yandex.ru
}

\section{Banin S.}

Central Russian Management Institute, Russian Academy of National Economy and Public Administration affiliated with the Russian President

Orel, Russia

e-mail: zaoexpert@mail.ru

\author{
Kidanova N \\ Belgorod Law Institute of the Ministry of Internal Affairs of \\ Russia named after I.D. Putilin \\ Belgorod, Russia \\ e-mail: natalykd2014@mail.ru \\ Plyakina A. \\ Voronezh state agrarian University named after Emperor \\ Peter I \\ Voronezh, Russia \\ e-mail: aplyakina@mail.ru
}

\begin{abstract}
The current state of the agro-industrial complex is characterized by a difficult economic situation, which is caused by the instability of relations at the international level, the introduction of economic sanctions on food imports, and the retaliatory embargo of the Russian state on a number of exported raw materials and products. All this requires agricultural enterprises to find effective ways and techniques for managing agricultural business in order to maximize profits. A special role is assigned to the functioning of integrated agro-industrial formations, which concentrate in their activities a huge resource and property potential. The article discusses ways to improve the ways of managing the property complex based on the assessment of fixed and working capital, the development of analytical tools that form information for external and internal stakeholders who can make management decisions to increase the cost of capital, increase production by attracting investment funds that improve the quality of agricultural products, taking into account the needs of the population.
\end{abstract}

Keywords - management, analysis, property, capital, methods, valuation.

\section{INTRODUCTION}

The primary strategic task of agricultural enterprises in market conditions is to meet the needs of Russian citizens in certain products [1], with a high level of consumer properties and quality at low costs, and to provide production and processing enterprises with raw materials. Among the identified problems in a vast space of diverse business operations, the main task is to profit from agricultural production [2], increase the profitability of the business. These indicators are an indicator of the correctness of the selected agrarian strategy for the management of the agricultural enterprise, the analysis of the internal environment [3].
Achieving the expected positive results and increasing capital depends on the availability and state of the economic entity's property potential, the main components of the property complex. For effective management of the property complex of integrated agro-industrial enterprises, it is necessary to make a reliable assessment of them, to choose the right analytical procedures that determine the tools for obtaining information necessary for making management decisions.

In modern conditions of the crisis, the composition of the property complex is subject to active movement due to changes in the status of agricultural enterprises, the scale of agricultural production, and stability in the food market. In this regard, the relevance of the methods and techniques used for assessing property, both for individual objects and in General the entire property complex, which acts as collateral for loans and loans, as a guarantee of securing obligations in settlements with contractors, an evaluation criterion for the functioning of an agricultural enterprise, the result of business development, increases.

\section{METHODOLOGICAL BASIS OF THE RESEARCH}

The development of agricultural activities and agricultural business is associated with the performance of various operations and transactions with the objects of the property complex of integrated agro-industrial enterprises [4], which in the market conditions has formed the need to determine their value, the formation of criteria and the composition of indicators for evaluating and analyzing objects. There is an urgent need to study land resources, their effective use with maximum return, grown products on which have the maximum demand in the food market [5]. 
Article 132 of the civil code of the Russian Federation characterizes any enterprise, including agricultural one, as a property complex necessary for the functioning and development of agricultural business [6]. The composition of the objects of the property complex is determined by the right of the enterprise to own assets. The list of assets depends on the specifics of the economic entity, industry orientation, and business scale [7].

The property of an integrated agro-industrial formation may include non-current and current assets, including tangible and intangible objects. The main types of non-current assets are: land plots, capital and financial investments of a longterm nature, agricultural machinery, machinery and equipment, vehicles, intangible assets in the form of trademarks, trade brands, know-how, rights to use innovative agricultural technologies for production and processing of agricultural products.

More diverse is the composition of current assets that participate in the value of the property complex, the total cost of capital of an agricultural enterprise, including raw materials in the form of seeds, feed, fuel and lubricants, fertilizers, finished products, funds in calculations, monetary and foreign exchange funds.

In the economic literature, there are different points of view on the valuation of the property complex, which is often adapted to the concepts of the cost of capital and the cost of business. Meanwhile, to make management decisions on operations with the property complex, it is necessary to distinguish the methods and techniques of its assessment from the assessment of the business of an agricultural enterprise.

In particular, from the point of view of A.I. Zimin, the cost of the enterprise is considered from the position of the product, which should be considered as the probable price of its sale, defining the enterprise as a product with a certain utility and the amount of costs to obtain it [8].

A different position can be traced in the works of A.G. Gryaznova and M.A. Fedotova, who generalize the assessment of the value of property and business value, considering their monetary value by determining the potential and real income from their use for a certain period, taking into account market conditions [9].

Kirdyashova I.V., believes that the property complex is part of the business and when evaluating it is necessary to distinguish between these concepts and their characteristics [10]. The property complex must be assessed in monetary terms, including the value of assets on the balance sheet of the organization used for organizing and conducting business, including non-current and current assets, as well as property obligations.

This point of view is defined by V.E. Esipov, who believes that despite a number of common features of the property complex and business, they are completely different concepts in their essence and, accordingly, require different approaches to evaluation.

We adhere to this position in the difference of approaches to the assessment of the property complex and the assessment of business, including in the agricultural sector of the economy. The main difference in assessing the property complex is to determine the value of its elements at the current date, without taking into account the effectiveness of their use in agricultural production in the future.

When evaluating agricultural business, the key position is to determine and analyze the achieved and expected results of integrated agro-industrial formation, both as a whole for the subject, and by individual structural divisions, industry sectors, types of activities, and types of capital [11]. In this regard, a list of criteria and indicators should be defined for assessing the property complex and agricultural business (figure 1).

\section{Estimated characteristics of an integrated agro-industrial formation}



Fig. 1. Criteria for assessing the property complex and the cost of agricultural business

According to the authors, the assessment of the property complex of agricultural enterprises is a component in determining the value of the agricultural business.

Various methods can be used to evaluate objects in the property complex: assessment of the actual original cost of objects, which is formed when purchasing an object and obtaining ownership rights to it (purchase, construction of an 
object) [12]; assessment of the current replacement cost when revaluing objects, modernization, reconstruction; assessment of the sale price or market value formed on the internal or external food and resource market [13]; fair value; assessment of the liquidation value of objects that were previously in operation; replacement cost; the residual value of the depreciable property minus the amount of accumulated depreciation; at the market value of shipped products, in relation to accounts receivable [14]; at the discounted value of objects, etc.

Legally approved approaches to assessing the property complex are the income method, comparative assessment, and the cost method.

For management purposes, the most acceptable method in integrated agro-industrial formations is the balance sheet method of property valuation, based on the application of accounting data and including methods and techniques of valuation for the purpose of accounting for current and noncurrent assets.

\section{RESULTS OF THE DISCUSSION STUDY}

A practical study of the property complex assessment was carried out on the example of the integrated agro-industrial formation of LLC "Selkhozinvest" in Orel. The main activities of the company are the cultivation of cereals (except rice), legumes and oilseeds, processing of cereals for cereals, breeding dairy cattle.

The property was assessed according to the balance sheet with the allocation of fixed and working capital (table 1).

TABLE I. DYNAMICS OF THE PROPERTY VALUE OF LLC "SELKHOZINVEST" OREL, THOUSAND RUBLES

\begin{tabular}{|c|c|c|c|c|c|c|}
\hline $\begin{array}{c}\text { The growth } \\
\text { rate of property }\end{array}$ & 2013 & 2014 & 2015 & 2016 & 2017 & 2018 \\
\hline $\begin{array}{l}\text { Cost of fixed } \\
\text { capital }\end{array}$ & 239726 & 301694 & 333013 & 396833 & 583335 & 613726 \\
\hline $\begin{array}{l}\text { basic growth rates, } \\
\%\end{array}$ & 100.0 & 125.9 & 138.9 & 165.5 & 243.3 & 256.0 \\
\hline $\begin{array}{l}\text { chain growth rates, } \\
\%\end{array}$ & 100.0 & 125.9 & 110.4 & 119.2 & 147.0 & 105.2 \\
\hline $\begin{array}{l}\text { Cost of working } \\
\text { capital }\end{array}$ & 614637 & 1166639 & 1271909 & 1344358 & 1368482 & 1554345 \\
\hline $\begin{array}{l}\text { basic growth rates, } \\
\%\end{array}$ & 100.0 & 189.8 & 206.9 & 218.7 & 222.6 & 252.9 \\
\hline $\begin{array}{l}\text { chain growth rates, } \\
\%\end{array}$ & 100.0 & 189.8 & 109.0 & 105.7 & 101.8 & 113.6 \\
\hline $\begin{array}{l}\text { Total value of the } \\
\text { property }\end{array}$ & 854363 & 1468333 & 1604922 & 1741191 & 1951817 & 2168071 \\
\hline $\begin{array}{l}\text { basic growth rates, } \\
\%\end{array}$ & 100.0 & 171.9 & 187.9 & 203.8 & 228.5 & 253.8 \\
\hline $\begin{array}{l}\text { chain growth rates, } \\
\%\end{array}$ & 100.0 & 171.9 & 109.3 & 108.5 & 112.1 & 111.1 \\
\hline
\end{tabular}

As the analysis showed, the value of the property of the integrated agricultural enterprise SelkhozInvest LLC in dynamics is characterized by a growth trend. In 2018 it amounted to 2168071 rubles. Over a six-year period, the cost has increased 2.5 times. Annual growth, as shown by chain growth rates, varied unevenly.

The composition of the property of SelkhozInvest LLC is characterized by the cost of fixed and working capital, and the cost of each type of capital also increased annually. The amount of working capital is approximately three times the value of fixed capital. In 2018, working capital amounted to 1554345 thousand rubles, and fixed capital was equal to 613726 thousand rubles. In dynamics, fixed capital increased much faster than fixed capital. The basic growth rate of fixed capital in 2018 compared to 2013 amounted to $256.0 \%$, the basic growth rate of working capital for six years is $252.9 \%$.

The average annual growth by types of capital was mixed. According to chain growth rates, the cost of fixed capital increased annually, with the exception of 2018, namely, in the past 2017. The growth rate was $147.0 \%$, and in 2018 it was only $105.2 \%$.

The reverse situation is observed in working capital for annual chain growth rates, at which a decrease was observed until 2017, and in 2018 the growth rate was $113.6 \%$. The change in the value of property in the composition of fixed and working capital is graphically presented in the form of a diagram in Figure 2.

The balance method allows making an assessment of the formation of the value of property not only by types of capital, but also by the elements that make up the fixed and working capital.

Valuation of fixed capital was carried out at the residual value for the past and current period. In its composition, for the studied integrated agricultural enterprise SelkhozInvest LLC, fixed assets, the value of which increased annually as a result of the purchase and construction of facilities and other non-current assets. In 2018, the value of these assets amounted to 569,479 thousand rubles, which is $8.3 \%$ higher than the value of objects in the past year.

Analysis of the dynamics of the value of property by type for six years of operation of an agricultural enterprise is shown in table 2.

The following elements are included in the working capital structure: stocks of materials and finished products intended for sale, receivables; short-term financial investments for up to 12 months; cash on hand and in the accounts of the organization. All of the listed assets are evaluated in the accounting system in various ways, which must be taken into account when determining the value of the property complex and for managing operations and transactions with property. 

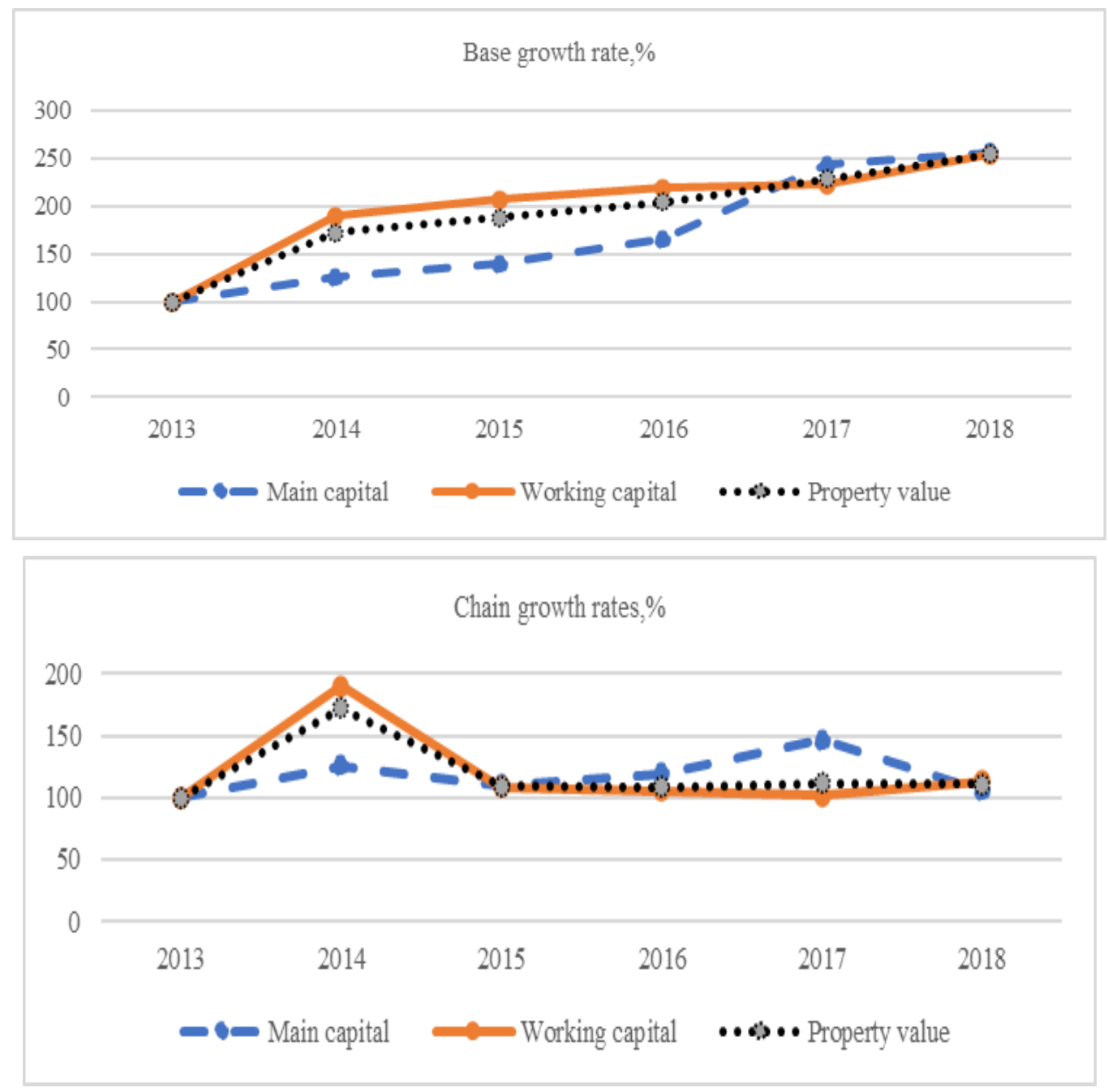

Fig. 2. Graph of the dynamics of the value of the property of LLC "SelkhozInvest" Orel

TABLE II. DYNAMICS OF THE VALUE OF THE PROPERTY OF LLC “SELKHOZINVEST” ORYOL, THOUSAND RUBLES

\begin{tabular}{|c|c|c|c|c|c|c|}
\hline $\begin{array}{c}\text { Property value per } \\
\text { item }\end{array}$ & 2013 & 2014 & 2015 & 2016 & 2017 & 2018 \\
\hline Cost of fixed capital & 239726 & 301694 & 333013 & 396833 & 583335 & 613726 \\
\hline $\begin{array}{l}\text { including: } \\
\text { Residual value of fixed } \\
\text { assets }\end{array}$ & 233370 & 295328 & 326657 & 390467 & 525861 & 569479 \\
\hline Other noncurrent assets & 6356 & 6366 & 6356 & 6366 & 57474 & 44247 \\
\hline Working capital value & 614637 & 1166639 & 1271909 & 1344358 & 1368482 & 1554345 \\
\hline $\begin{array}{l}\text { including: } \\
\text { Actual cost of } \\
\text { inventory }\end{array}$ & 127833 & 229775 & 261003 & 243832 & 363989 & 368338 \\
\hline Amount of receivables & 226615 & 640282 & 712227 & 900928 & 820277 & 953926 \\
\hline $\begin{array}{l}\text { Actual (initial) value of } \\
\text { financial investments }\end{array}$ & 258870 & 295934 & 266504 & 197050 & 157457 & 154116 \\
\hline Cash & 1319 & 648 & 32175 & 2548 & 324 & 65247 \\
\hline $\begin{array}{l}\text { The total value of the } \\
\text { property of the } \\
\text { enterprise }\end{array}$ & 854363 & 1468333 & 1604922 & 1741191 & 1951817 & 2168071 \\
\hline
\end{tabular}


The analysis of the elements of working capital indicates that stocks are increasing annually, the highest growth rate occurred in 2014 and 2017, in which favorable conditions were observed for growing and harvesting crops.

In 2018, a noticeable change occurs in relation to financial and other current assets, which include receivables. In 2018 , this indicator is growing in relation to 2017 by $16.3 \%$. This situation is a positive change, as it indicates that the receivables are short-term, and the organization's funds are in constant circulation, generating income. However, the growth of receivables may be characterized by the diversion of funds from the organization's turnover, which requires additional research.

A visual representation of the composition of the property and its changes in dynamics is presented in Figure 3.

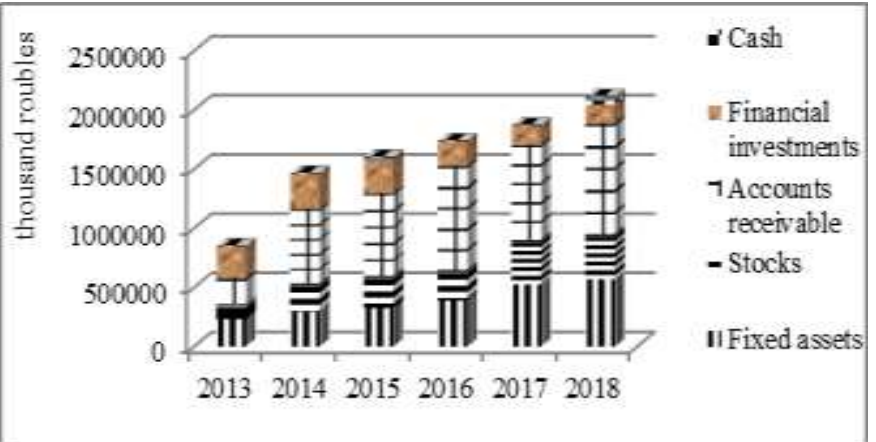

Fig. 3. Diagram of the dynamics of the composition of the property of LLC "SelkhozInvest"

The annual decrease is observed in financial investments, from 295934 thousand rubles. in 2014, their amount decreased to 154,116 thousand rubles. In relation to 2017 , financial investments amounted to $97.9 \%$. This situation indicates an annual decrease in free cash in circulation of the organization, which serve to generate additional income from the use of working capital.

A positive fact in the use of working capital is a sharp increase in cash on hand and in settlement accounts, which is a factor in improving the liquidity of SelkhozInvest LLC.

Assessment of the agricultural business of integrated agroindustrial groups is characterized by a wider range of criteria and indicative indicators [15]. Assessment of the property complex is one of the components for organizing entrepreneurial activities. The composition of the assessment criteria covers: the cost of human capital, the level of innovation in agricultural production, the image and business reputation of an agricultural company, and the demand for agricultural products that are produced and processed.

\section{CONCLUSION BASED ON THE RESULTS OF THE STUDY}

According to the results of the study, it should be noted that the assessment of the property complex, its individual elements and the business of the agricultural enterprise provides for the fulfillment of a number of requirements for the delimitation of criteria and indicative indicators for these objects. With regard to the assessment of the property complex, the methods and techniques used should contribute to the formation of reliable information on the cost necessary to complete operations and transactions with property, develop the material base, disseminate areas of the integration management system, improve the agricultural business in order to improve the quality of food in order to ensure food security of the state.

\section{References}

[1] V.G. Zakshevsky, O.G. Charykova, I.N. Merenkova, "Strategic priorities for developing the agro-industrial complex and rural areas of theregion", IOP Conf. Ser. Earth and Environmental Sci., p. 012007, 2019.

[2] A.V. Ulezko, A.A.Tyutyunikov, A.P. Kurnosov, "Theoretical and methodological aspects of designing prospective models for agricultural development", IOP Conf. Ser. Earth and Environmental Sci. p. 012063,2019

[3] V.A. Bogdanova, E.A. Kyshtymova, "Analysis of the environment of the company as the most important stage of strategic management", pp. 79-83, 2016 [Coll. of sci. papers Int. Econ. Forum Bakaniv Readings Modern concepts of accounting, analysis and audit in the development of entrepreneurship]. (Orel, 26 November 2015). Orel: Publ. house OrelGIET.

[4] T.I. Gulyaeva, O.V. Sidorenko, "To the question of land use in the Oryol region”, Bull. of agrar. Sci., no. 6, pp. 93-100, 2017.

[5] I.N. Merenkova, A.V. Agibalov, V.A. Lubkov, "Resources for the transition of rural areas to a diversified development model", IOP Conf. Ser. Earth and Environmental Sci., p. 012020, 2019.

[6] Civil Code of the Russian Federation (Part One) of 30 November 1994, no. 51-Ф3 (as amended on 12/16/2019, as amended on 05/12/2020) Retrieved from: http://www.consultant.ru/document/cons_doc_LAW_5142/

[7] S.N. Banin, "The impact of the value of assets on the management of the property status of the organization", Bull. of OrelGIET, vol. 3 no. 45, pp. 193-199, 2018

[8] A.I. Zimin, Property Valuation: Questions and Answers. Moscow: Jurisprudence, 2007, $240 \mathrm{p}$

[9] A.G. Gryaznova, M.A. Fedotova (ed.), Business Valuation, Textbook. Moscow: Finance and Statist., 2001, 736 p.

[10] I.V. Kirdyashova, Valuation of the property complex of an enterprise in a business valuation system. Retrieved from: https:// cyberleninka.ru/article/n/otsenka-imuschestvennogo-kompleksapredpriyatiya-v-sisteme-otsenki-biznesa

[11] N. Lytneva, N. Parushina, A. Polyanin, E. Kyshtymova, Y. Vertakova, "Methods of complex analysis in management of commercial organizations owned capita”, pp. 2126-2134, 2017 [Proc. of the 29th Int. Busin. Inform. Manag. Associat. Conf. Education Excellence and Innovation Management through Vision 2020: From Regional Development Sustainability to Global Economic Growth 29].

[12] N.V. Parushina, O.A. Efimina, "Management of the working capital of an enterprise based on the use of economic and mathematical models", Sci. notes OrelGIET, no 2, pp. 149-152, 2010.

[13] Yu.M. Petrova, Scientific approaches to the development of the concept of working capital management, Modern trends in the development of management and public administration. Orel: Publ. House of Public Found. RANEPA, 2016, pp. 285-288.

[14] V.B. Malitskaya, M.B Chirkova., V.G. Shirobokov, N.N. Volkova, "Development of account receivable management in Russia", pp. 723-728, 2019 [Proc. of the 33th Int. Busin. Inform. Manag. Associat. Conf. (IBIMA 2019) Education Excellence and Innovation Management through Vision 2020].

[15] C. Grechaniuk, Yu. Petrova, "The effectiveness of integration processes in the agricultural sector", Econ. of agricult. and proc. enterprises, no. 2, p. 26, 2001. 